\title{
THE FEEDBACK ELABORATION AND ITS IMPLICATIONS TOWARDS INDONESIAN SUBJECT
}

\author{
Jepri. Universiti Tun Hussein Onn Malaysia \\ Jefrikamil10@gmail.com \\ Yusmarwati Binti Yusof. Universiti Tun Hussein Onn Malaysia \\ marwati@uthm.edu.id \\ Atmadinata. Universitas Negeri Jakarta \\ drs.atmadinata@gmail.com \\ Said Nuwrun. Universitas Karimun \\ saidnuwrun84@gmail.com \\ Alpino Susanto.Universitas Putera Batam \\ susanto.alpino40@gmail.com
}

\begin{abstract}
Learning Indonesian as a school subject can be intended as an effort to develop Indonesian language functions for Senior High School students to obtain information, control behavior, interact with others, express personal feelings or intentions, develop learning skills, and use language to convey information. To achieve this purpose, the teacher must do learning optimally. This paper aims to elaborate on the various phenomena of learning Indonesian in Senior High school and various references as the basis of language and conclusions. The elaboration feedback strategy is the focus of this paper and intended as a discourse and input for the teacher as the person in charge of learning process in the classroom.
\end{abstract}

Keywords: Elaboration Feedback, Implications, Indonesian Language Subject

\section{INTRODUCTION}

Various efforts have been made to improve education, reorient the objectives of the Education curriculum, and to improve the learning system in schools. But the lack of understanding and commitment about the nature of education and the learning process in schools as a tool to develop the potential of students in the context of human resource development is still felt.

Efforts to develop students' potential, existing subjects in schools have an important role as providers of information and development of thought processes. The end of this effort is the learning process that can change students' behavior cognitive, affective, and psychomotor.

The focus of the discussion in this paper is Indonesian language as a subject. This subject has the same duties and responsibilities as other subjects in developing student potential. Language allows humans to interact (communicate), share experiences, learn from each other, and improve intellectual abilities.

Problems with learning Indonesian language such as incomplete learning facilities, learning methods used, teachers who do not develop students' language skills, the material delivered emphasizes language principles rather than practical interests, achieving curriculum targets is too strict, so teachers pay less attention 
to differences in students learning, and it is believed that there is a difference between lowability and high-ability students to havethe lessons. The other problem is the low motivation of students to study Indonesian Language Subjects and the attitudes and behavior of teachers are less oriented to the nature of students who learn. The low motivation of students is due to a variety of negative student behaviors that arise when the teacher delivers learning material. As a result, the results of learning Indonesian in most students have not been satisfactory.

The low learning outcomes are also caused by inaccuracies in the management of learning by teachers because they lack attention to the principles of learning in developing motivation to learn. The learning process seems to be able to turn off passion for learning because teachers are less creative. The teacher dominates more in learning activities, and less activates students in gaining knowledge from the learning material delivered.

The learning process in a large number of classes makes the teacher deliver the learning material in one direction without any feedback from students. The weakness of the learning process becomes monotonous and the teacher has no effort to find out whether students have understood the material presented or not. As a result, not a few students who did not appear to have self-confidence (self confidence), showed high anxiety, did not have good motivation when facing assignments or tests given by the teacher.

Another phenomenon that arises is the way the teacher responds to the tasks that students have done without feedback. Though feedback in this case is quite important because the tasks done are not always as expected. The learning process that is not done by giving feedback makes students slow in learning. This is because students are not aware of mistakes and limitations and do not know clearly how they should do it. if this is allowed to drag on, it is feared students will become frustrated and lose their self-confidence.

\section{LITERATURE REVIEW}

Several literature studies that can be used as references in discussing phenomena and issues that develop in learning Indonesian as a subject in school.

\subsection{Indonesian Language Learning}

The development of technology and the advancement of science, especially in the field of psychology, have given rise to various learning concepts, for example the learning theory of Classical Conditioning with Ivan Pavlov's figure. Theory of Learning Connectionism with Edward L. Thorndike which states learning is a process of strengthening and understanding the response to stimulus with a principle called the Law of effect. Learning theories that continue to evolve lead to the formulation of the notion of learning by other experts. But the most important thing according to Rogers (in Tung, 2015) states that education should make learning and teaching more humane, more meaningful and more personal. In line with Rogers's opinion, Cronback (in Suryabrata, 1995), states that "learning is a change in performance as a result of practice". In the same source McGeoh (Suryabrata, 1995) states that "learning is a change in performance as a result of practice". The definition of learning according to these two experts is change in behavior as a result and practice or experience. According to Prayitno 
(1994) that "learning is an attempt to master something new by utilizing what is in an individual", something new from the learning process can be within the limits of knowledge, understanding, feelings, skills and experience. Something new is certainly obtained by students through the learning process.

The concept of learning from the experts above shows that learning is an active process carried out by students with their environment.

This process involves all physical and psychological aspects and occurs in the form of practice and practice. The results of the process produce changes in him in the form of knowledge, understanding, skills, attitudes and values and experiences that are relatively stable. According to Dhieni (2011), the way children use language will affect social, emotional, physical, and cognitive development. And then he further stated, with language, children can communicate their intentions, goals, thoughts and feelings to others.

Indonesian Language learning is essentially the development of language skills including reading, writing, listening and speaking skills. This skill is seen as an integrative learning activity. Because the smooth communication of a person depends on optimal mastery of the language skills. In language learning, the skills needed are the ability of students to arrange words into sentences, understand sentence patterns, and develop various vocabulary. All of that is used to communicate. Smooth communication is the starting point for language clarification. In addition, the knowledge of language provided consists of language knowledge consisting of vocabulary and structure and language skills such as listening, speaking, reading and writing.
According to Halliday (in Mulyati, 2013) and Sapani (1997), there are seven language functions for students who learn languages: 1) Instrumental functions, namely using language to get something, 2) Function of regulators, namely using language to control the behavior of others , 3) The function of interaction, which is using language to interact with others, 4) Personal functions, namely using language to express personal feelings or intentions, 5) Heuristic functions, namely using language to learn and discover, 6) Imaginative functions, namely using language to create imagination and 7) informative function, which is to use language to convey information.

Sapani (1997) explained that there are three principles that encourage student learning enthusiasm, namely as follows: 1) The principle of communication, namely teaching and learning activities in the class should be real communication, 2) Principles of duty, namely learning activities in the form of meaningful assignments, 3) The principle of meaningfulness, namely the language lesson taught, should be something meaningful and authentic.

From the mentioned experts' opinions on the nature of Indonesian language learning, it can be concluded that the essence of Indonesian language learning is the development of Indonesian language functions for students to obtain information, control the behavior of others, interact with others, express personal feelings or intentions, language to develop abilities learn and find, to create imagination and use language to convey information.

\section{DICUSSION}

\subsection{Teachers in Indonesian Language Learning}


Teacher has two main functions, namely as an educator and teacher. However, the two terms cannot be separated, because both refer to a process that changes students' attitudes and abilities to become someone better after the process that is followed.

The success of the teacher in the management of the learning process needs to be increased in competence. Teachers must be aware and responsive to the changing times, professionally qualified, rational, democratic and nationally minded and of high morality and faith (Anwar, 2008). To achieve these competencies, a teacher must be able to master the knowledge taught, skilled in choosing a source book, respecting his profession, meticulously choosing a method, being able to manage the class, having the skills to perform tasks, having the ability to integrate with students, being able to guide students, and evaluating student learning.

On the other hand Sudjana (2006) divides three competencies; First, cognitive field competence, meaning intellectual ability, such as mastery of subject matter knowledge on how to teach, knowledge of how to learn and individual behavior, knowledge of class administration, knowledge of assessing student learning outcomes and so on; Second, competency in the field of attitude, meaning readiness and willingness towards various matters relating to the task and its profession, for example, respecting his work and having a strong will to improve the results of his work; Third, behavioral competence (performance), which means ability in various teaching skills, weighing, evaluating using teaching aids, communicating with students, skills to foster students' enthusiasm and others.
According to Roijakkers (1991), so that the learning process can run well, the instructor can carry out two types of activities, namely general and special activities. General activities are all activities carried out by the teacher when he teaches these general activities, namely; first there must be motivation; two, instructors must know what knowledge the students have; third, students need to be informed about what goals to achieve. Special activities are steps in the learning process that must be carried out by the teacher step by step.

\subsection{Learning Strategies}

Learning strategies have several meanings according to some experts, among them are learning strategies in the learning process, often said ways or techniques and tactics used by the teacher in general steps or acting in an effort to achieve the predetermined goals. In this paper, the term learning strategy is used with the same intent as above, namely the methods, techniques and tactics used in learning.

According to Sudjana (2000: 147) that the learning strategy is the effort of the teacher in using several teaching variables (goals, materials, methods and tools and evaluations) in order to influence students to achieve the stated goals. From the understanding it can be said that the learning strategy is the real action of the teacher or the practice of carrying out teaching in a certain way, which is, more effective and efficient.

In the learning strategy there are steps that must be done with the components that exist in learning (Suparman, 1995). Then Djamarah (1996) explains that if it is associated with teaching and learning, strategies can be interpreted as general patterns of teacher 
activities, students in the realization of teaching and learning activities to achieve the goals that have been conceived.

Other experts see strategies as determining the components of teaching for the achievement of learning goals, as stated by Soekartawi (1995) that teaching strategies are the determination of the main learning components so that the presentation of learning content can achieve learning goals and can be understood by students effectively and efficiently.

In line with these opinions, Sudjana (2000: 148) explains that there are basic things that must be considered by the teacher in implementing the learning strategy. First, the stages of teaching; second, the use of models or learning approaches. and; the third is the use of teaching principles. At the instructional stage the teacher gives questions and assignments to know the level of understanding of each subject matter discussed. If it turns out students don't understand it yet. Then the teacher repeats the subject matter before proceeding to the next subject matter.

From several opinions that have been put forward, it can be concluded that the learning strategy is the steps or procedures that have been chosen by the teacher who can provide students with the aim of achieving learning objectives optimally. The following is explained in connection with the learning strategy

\subsection{Feedback Elaboration}

Ruky (2000) explains that in the context of the communication process, feedback is the response given by the recipient of the message to the sender of the message in the form of a statement that he has received and understood the message, or an additional explanation request. This feedback is usually given immediately or spontaneously once the message is received.

Referring to this definition, feedback is associated with the learning process so feedback can be made both from the recipient of the message (student) to the sender of the message (teacher) or from the sender (teacher) to the recipient of the message (students) with the intention of obtaining information about how the achievement learning that has been done.

In learning, feedback is one of the learning events (instructional event), therefore feedback is said to be a communication or procedure that is given to inform students about the accuracy of an answer, usually on questions in learning. Then Rooijakkers (1991) explains that feedback is only intended to find information about where students are about the material that has been discussed, besides that students are also given the opportunity to force themselves to where they are working on the material, so that they can complete incomplete understandings.

Based on the definition of feedback above, there are several things that can be stated. First; feedback is the provision of information to students about the progress that has been achieved towards the task or work that has been done, thus knowing whether he succeeded or not in completing the task or work. Second, feedback must be given to students as soon as possible after they have completed their work and carried out continuously so that they know about their progress. So that in the next learning process students act on the right information and can be trusted.

According to Podo and Sullivan (1991), elaboration implies "to elaborate on". 
Furthermore, Podo and Sullivan (1991) also explain that elaboration has the meaning of giving further information (to elaborate). Meanwhile, Chernow (2002) asserts that elaboration is defined as 'elaborate' (elaborate) which means giving full attention to a subject and adding details. Then in line with this opinion, Supriadi (1998: 7) suggests that elaboration is to describe something in detail. Based on these three opinions, limitations can be given that the term elaboration is synonymous with explaining or giving further information or outlining.

In the context of learning, elaboration has a deeper meaning. Abizar (1995) emphasizes that elaboration is the addition of information to information or knowledge that is to be learned. Additions to information in elaboration can be done by means of logical inferences, examples, details and symbols. Thus elaboration can give meaning to the new knowledge that is to be learned higher, which in a further step leads to the strengthening of new knowledge in one's knowledge system. This gives an indication that elaboration can optimize the acquisition of knowledge.

Dahar (2008) explains that elaboration is the process of adding related knowledge to the information being studied. In this case the elaboration facilitates the calling in two ways, namely; First, elaboration provides alternative ways to call for activation to spread. So if one way to find a dead end, then other methods still exist; second, elaboration provides additional information that can be useful for constructing answers. Dempsey, Driscoll, and Swindell (in Mory, 1996) Explain that the major variables in most corrective feedback studies are as follows: 1) No feedback; 2) Simple verification feedback or knowledge of result (KR); 3) Correct response feedback or knowledge or correct response (KCR); 4) Elaborated feedback, and; 5) Try again feedback. Then Dempsey, Driscoll, and Swindell (in Mory, 1996) explained that elaborated feedback provides an explanation for why the learner responds correctly or allows the learner to review part of the instruction.

Dempsey, Driscoll, and Swindell. Roper (in Slameto, 1989) distinguishes the feedback level as follows; 10 Level I: No feedback; 2) Level II: Feedback in the form of incorrect or correct information; 3) Level III: Feedback in the form of incorrect or correct information coupled with the correct answer (KCR: "Knowledge of the correct response"); 4) Level IV: KCR + explanation; 5) Level V: KCR + additional teaching.Mory (1996) further explains that if feedback is done to improve functions, the simplest feedback verifies the correct or incorrect student answers. This verification is usually combined with an elaboration component to provide more information for students.

Kulhavy and Stock (in Mory, 1996) explain that there are three possible types of elaboration that occur during feedback, namely 1) Specific tasks; where described from the request of the task and question (reviewing the task or question with the correct answer; 2) Basic instructions; contains information obtained from specific subject matter, but not directly the actual question before feedback (explanation of the correct answer), and; 3) Extra instructions; where the provision of additional information from outside for the development of subject matter.

From a number of expert opinions, it can be concluded that elaboration feedback is an attempt to explain more information about the 
response given by students through work or training that has been done, so that students know correctly or not the response given.

\subsection{The Purpose of Providing Feedback Elaboration}

The implementation of the teaching and learning process does not always achieve maximum results, because there are still shortcomings made by the teacher in handling student learning processes. In connection with the lack of implementation of tasks in solving the problems students are working on, feedback is needed.

According to Budiardjo (2001) that students who have completed the task usually want to know the extent to which these tasks have reached a predetermined standard or standard. Correspondingly, Utomo (1990) argues that errors can be classified as systematic errors that show inaccuracies in dealing with problems, errors that indicate the inaccuracy of the use of learning material, and errors caused by inaccuracy.

The feedback given must link the results that have been achieved by students with the goals they want to achieve so that students see the gaps or shortcomings that exist. However, if the gaps are informed by the teacher to students without information on follow-up or suggestions for improvement, students who answer incorrectly will still find it difficult to correct their mistakes because the learning process is not helped. Thus giving the right information is intended to provide opportunities and help students learn to find the answers correctly.

Feedback can build self-confidence, rather than giving a judgmental reaction to one's performance, continuous dialogue can help direct the person, whether he is successful or failed. Confidence is formed because of the informative feedback on the less-than-fast response that has been made. So that every time they work on the same knowledge they will give the right response. Suryabrata (1998) asserts that repetition only brings results if there are other factors that work causing effective repetition (success). Repetition will bring results if followed or accompanied by rewards or suggestions (feedback) not only repeated.

The task of the teacher as an educator, must provide opportunities through feedback (feedback) to students to explore things that have not been understood by stimulating students motivation to force them to test whether they have understood the material given, as Rooijakkers (1991: 66) states that " Teachers who are aware that the new learning process can be aroused if students are always forced to explore what they already know, will give feedback in a variety of ways ".

Stimulation given by the teacher in the form of feedback will generate motivation for students to learn. As stated by Hudoyo (1997) that "Explanation on the results achieved by students is one of the wrong techniques that are" done to motivate students in learning ". This is confirmed again by Prayitno (2006) who states, will arise excitement and desire to further improve learning activities in students, if he knows the progress that has been achieved.

From the quotation above, it is clear that the explanatory feedback in front of the class can serve as a warning so that students are careful in doing their next assignments. Each student will try to better understand which parts of the lesson they lack to understand. So that students better understand the material being taught and obtain 
higher results, if if a student has understood eighty percent of the material provided with an explanation again it is expected that students will try to understand twenty percent more of the material that has been studied.

Providing explanatory comments in front of the class on student assignments means a teacher also adds information to students. So that with this feedback information can improve learning outcomes (Semiawan, 1992).

From some expert opinions about the purpose of giving feedback in the learning process, it can be concluded that the purpose of giving feedback is; 1) to find out how far the results (appearance) that have been achieved by students with the learning objectives to be achieved so that students can see gaps or shortcomings that exist; 2) As an effective requirement for training students' cognitive skills; 3) Give assistance and determine what type of assistance students still need; 4) Helps maintain students' interest and enthusiasm (motivation) in learning; 5) Build students' confidence in learning, and; 6) Improve the results or student achievement.

\subsection{Learning Outcomes}

Learning is a physical and psychological activity, therefore the results achieved from learning activities involve changes in both aspects. According to Ahmadi (1997) that learning is physical or physical activities. The result is physical changes. Besides that learning is a spiritual or psychic activity. Learning outcomes achieved are changes in the soul such as obtaining an understanding of language, being moral and so on.

Gagne (1987) suggests that there are two learning definitions, namely: the process of gaining knowledge, skills, habits and behavior; and the process of mastering the knowledge or skills obtained from the process. To find out what is meant by learning, it can be seen in the important characteristics of learning, namely (1) learning is the process by which humans can do it, (2) learning generally involves interaction with the external environment, and (3) learning occurs changes in behavior and changes in a relatively long time in the lives of individuals.

Djamarah $(1997 ; 175)$ states that tangible evidence of improving student learning outcomes comes from an assessment in the field of education carried out by the teacher after students carry out learning activities. Learning outcomes indicate students' abilities determined in the form of numbers or values.

From the explanation above, it can be concluded that learning outcomes are a process of changing behavior which includes knowledge, skills; and attitudes that are learning outcomes and activities.

\subsection{The Implication of Feedback elaboration}

In the activities of the learning process often the teacher has difficulty in dividing the time of learning properly because too much material will be delivered and can also cause the material delivered is not too deep. To bridge this, all teachers can give assignments to students, with the hope that they can be done well by students. Tasks can be given various forms not only in the form of group assignments, but also in the form of individual duties. The assignment can be given by the teacher after completion of the teaching and learning activities.

Jamarah (1997) explains "Tasks are jobs that require implementation to be done well. Teachers can give assignments to students in 
various forms, not only in the form of group assignments, but can also be in the form of individual tasks ". Tasks are given to make the learning process fun, effective and efficient.

Students will learn more excited when they know they are getting good results. These good results will be a pleasant response and will have a good effect on your future learning efforts. Furthermore, the feedback develops into reinforcement or feedback for information. Feedback as reinforcement only tells students that the learning outcomes (answers) are right or wrong and do not provide corrections to the wrong answers. Feedback as information emphasizes its function to correct mistakes made by students. Therefore, this system of errors is very important.

The implications of feedback on learning are important to note because students always need certainty from activities that are done right or wrong. With the feedback of students about the extent to which they are compared to the learning objectives that must be achieved, this feedback provides information to students about success, failure and the level of competence so students will always have knowledge of the results which are also reinforcement for themselves. A student learns more if each step is immediately given reinforcement (Dimyati, 1994).

Worrel and Stiwell (in Soekamto, 1995: 70) provide some suggestions on how to manipulate feedback to facilitate the learning process of students, namely the teacher must be sure that the initial abilities needed have had students before he does his new task. The feedback given must be used to correct errors, feedback needs to be given regularly, don't be suspended. This means that assignments, exam results, reports and so on must be promptly examined and returned to students, if possible give the opportunity to students to control the feedback given by the teacher must provide corrective comments, students must be encouraged to try to correct mistakes, The teacher must give verbal feedback. That can provide incentives, for example by saying that you / other people are happy with what the students have done, and the teacher must provide feedback that can motivate students by stating that they must be happy with what they have tired, the name of the assignment they did was very interesting, and so on.

According to Usman

(2000)

reinforcement is any form of response, whether verbal or non-verbal, which is a chart of behavior modification that the teacher performs on student behavior, which aims to provide information or feedback to students for their actions as an act of encouragement or correction. Or reinforcement is a response to a behavior that can increase the likelihood of repetition of the behavior. These actions are intended to teach or encourage students so that they are more active in participating in learning interactions.

Furthermore, Usman (2000) explained that reinforcement has the effect of positive attitudes of students towards the learning process and aims to: (1) generate student motivation, (2) stimulate students to think well, (3) raise student attention, (4) cause the ability to take the initiative personally, and (5) control and change the negative attitudes of students in learning toward behaviors that support learning.

Sumantri (1999) argues that there are six types of reinforcement in learning according to the ongoing situation and conditions in the classroom, namely: verbal reinforcement, 
gestural reinforcement, approaching reinforcement, touch by touch, strengthening by providing pleasant activities and strengthening in the form of signs or objects.

The accuracy of the use of reinforcement must be considered. When reinforcement is used in inappropriate situations and times, the effectiveness will be lost. Conversely, if reinforcement is used appropriately in the learning process, this will have a positive effect on student learning activities. To go further, the teacher must also pay attention to things such as: (1) use different types of penyatan, (2) do not delay awarding, because it will become useless, (3) reinforcement can also be given to the wrong student response, by commenting on his courage to express his opinion.

There are five important things to be considered by the teacher in providing reinforcement to students, namely: (l) being warm and passion, (2) giving a positive impression to students, (3) having an impact on positive behavior (4) being personal or group and (5) avoiding negative responses. In this way, feedback can improve the appearance of students in relation to learning goals that must be achieved. According to Soekamto (1995: 70) that with the feedback, students can understand the extent to which their appearance is compared to the learning objectives that must be achieved".

Feedback provides information to students about their success, failure and competency level. Feedback means it can increase efforts to correct mistakes made by students, or make students rethink the problem at hand. In the management of the teaching and learning process it needs to be given realistic and consistent feedback and is constructive and specific. That is, the feedback is not confusing and can improve learning outcomes and generate motivation.

Then based on the research conducted by Kamil (2005), the results of the study were obtained: First, the learning outcomes of students taught using elaboration feedback were significantly higher compared to the results of Indonesian language learning students taught using non elaboration feedback strategies; Second, the learning outcomes of students who have high learning motivation are taught by noncollaborative feedback strategies; Third, the learning outcomes of students who have low learning motivation taught by the elaboration feedback strategy are significantly higher compared to the learning outcomes of students who have low motivation who are taught with non-collaborative feedback strategies, and; Fourth, there is no interaction between learning strategies and learning motivation towards students' learning outcomes.

Based on these findings, it can be concluded that elaboration feedback strategies can improve student learning outcomes in Indonesian subjects, therefore elaboration feedback strategies need to be implemented incentive and continuously by the teacher.

\section{CONCLUSION}

Based on the description above, it can be concluded that the essence of Indonesian language learning is the development of Indonesian language functions for students to obtain information, control the behavior of others, interact with others, express personal feelings or intentions, language to develop learning and discovering abilities, to create imagination and use language to convey information. 
There are three competencies that must be possessed by the teacher to be more professional, namely the competency in the cognitive field (intellectual ability), attitude competence (readiness and readiness for various things that are compatible with the assignment and profession and behavioral competencies (teaching skills). steps or procedures that have been chosen by the teacher that can provide students with the aim to achieve learning objectives optimally. The following are explained in connection with the learning strategy.

Elaboration is an effort to explain more information about the response given by students through tasks or exercises that have been done, so that students know correctly or not the response given.

The intentions of giving feedback are; 1) to find out how far the results (appearance) that have been achieved by students with the learning objectives to be achieved so that students can see gaps or shortcomings that exist; 2) as an effective requirement for training students' cognitive skills; 3) to give assistance and determine what type of assistance students still need; 4) to help maintain students' interest and enthusiasm (motivation) in learning; 5) Build students' confidence in learning, and; 6) Improve the results or student achievement.

Elaboration feedback strategies can improve student learning outcomes in Indonesian language subjects, therefore elaboration feedback strategies need to be implemented in an incentive and continuously by the teacher in the learning process to improve student learning outcomes.

\section{REFERENCES}

Abizar. (1995). Strategi Intruksional: Latar Belakang Teori dan Penalarannya. Padang: FPTK IKIP Padang.

Ahmadi, A. (1997). Psikologi Umum. Surabaya: Bina Ilmu.

Ali, Muhammad. (1996). Guru Dalam Proses Belajar Mengajar. Bandung: Sinar Baru Algensido.

Budiardjo, L. (2001). Metode Pemberian Tugas. Jakarta: Universitas Terbuka.

Dhieni, Nurbiana. (2011). Metode Pengembangan Bahasa. Jakarta: Universitas Terbuka.

Djamarah, S., B. (1996). Strategi Belajar Mengajar. Jakarta: PT. Rineka Cipta.

Mulyati, Y. (2013). Bahasa Indonesia. Jakarta: Universitas Terbuka.

Munandar. (2001). Enseklopedia Pendidika. Edisi Pertama: Cetakan I Malang: UM Press.

Paunen, P. (2001). Konstruktivisme Dalam Pembelajaran. Jakarta; Universitas Terbuka.

Podo, Hadi., Sulliacan S., Joseph. (1991). Kamus Ungkapan Indonesia Inggris. Jakarta : PT. Gramedia.

Prayitno, and Erman, A. (1994). Dasar-dasar Bimbingan Dan Konseling. Jakarta: Dirjen Dikti Depdikbud.

Rooijakkers, Ad. (1991). Mengajar Dengan Sukses: Petunjuk Untuk Merencanakan dan Menyampaikan Pengajaran. Jakarta: PT Gramedia Widasarana Indonesia.

Sapani, H., Suardi, Yeti, M., and Nunny, S. (1997). Teori Pembelajaran Bahasa. Jakarta: P3G Depdikbud.

Semiawan, and Conny. (1992). Pendekatan Keterampilan Proses, Bagaimana Mengaktifkan Siswa Dalam Belajar. Jakarta: Gramedia.

Slameto, (1989). Psikologi Belajar. Bandung: Remaja Rosdakarya. 
Soekamto, Tuti. (1995). Teori Belajar Dan Model-Model Pembelajaran. Jakarta; Universitas Terbuka.

Soekartawi. (1994). Meningkatkan Rancangan Intruksional (Instruksional Design). Raja Grafindo Persada.

Sudjana. (1998). Dasar-Dasar Proses Belajar Mengajar. Bandung: Sinar Baru.

Sumantri, M. (1999). Strategi Belajar Mengajar. Jakarta: Proyek PGSD Dirjen Gikti Depertemen Pendidikan Dan Kebudayaan.

Suparman, A. (1995). Desain Intruksional. Jakarta: Dirjen Dikti

Supriadi, D. (1998). Kreativitas, Kebudayaan Dan Perkembangan Ilmu Pengetahuan Dan Teknologi. Bandung : CV. Alfabeta.

Suryabrata, S. (1998). Psikologi pendidikan. Jakarta: PT. Grafindo Persada.

Tung,K., Y.(2015). Pembelajaran dan Perkembangan Belajar. Jakarta: Indeks.

Usman, M. U. (2000). Menjadi Guru Profesional. Jakarta: Remaja Rosdakarya.

Utomo, T. (1990). Peningkatan Dan Pengembangan Pendidikan Manajemen Perkuliahan Dan Metode Perbaikan Pendidikan. Jakarta: Gramedia. 